\title{
THE PROBLEM OF PERSONALIZATION AND PERSONIFICATION OF PROFESSIONAL TRAINING AND ITS IMPLEMENTATION IN HIGHER EDUCATION INSTITUTIONS AS A NEED OF TIME
}

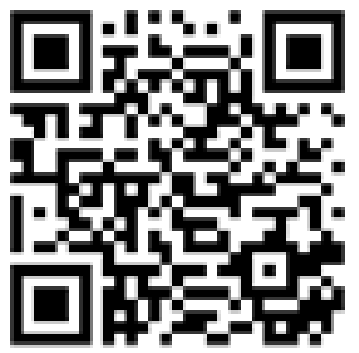

To cite this article:

\author{
Svitlana Martynenko, Dr. Sc., Prof. \\ Vice-Rector for Scientific and Pedagogical Work, \\ Kyiv International University \\ Kyiv, Ukraine \\ s-martunenko@ukr.net \\ https://orcid.org/0000-0002-7822-5600
}

Martynenko, S. (2021). The problem of personalization and personification of professional training and its implementation in higher education institutions as a need of time. Education: Modern Discourses, (4), 164-168.

https://doi.org/10.37472/2617-3107-2021-4-16

Abstract. Professional training in the context of reforming the educational sphere acquires new aspects and forms of implementation of educational programs, taking into account the personality-oriented trajectory of individual professional growth of each subject in the educational process. The solution to the problem is relevant in our time: what is important in the process of personal and professional development - personalization or personification of the educational process? The paper reflects the features of personalization and personification of specialists' professional training, discloses and clarifies their essence, presents an analysis of scientific publications dedicated to this problem; it emphasizes the necessity of introducing a personalized approach, which is an important means of achieving this goal. The theoretical foundations of the personalization and personification of professional training, the peculiarities of the organization of educational activities, covering the cognitive, informational, scientific and innovative, social, managerial spheres, have been characterized. It has been proved that the important conditions for the personalization of the educational process at higher educational establishments is a cultural impulse in the idea of democratization and construction of society and a human, the tradition of social and humanitarian thought, individualization of education, etc.

Keywords: personalization; personification; professional training; personalized approach; higher educational establishments.

\section{INTRODUCTION. PROBLEM STATEMENT}

In modern conditions of development of higher education system, taking into account the opportunities that online education provides, professional training will change for sure its 
vector from a conveyor model to a personality-oriented one, which will become personalized and individually adapted for each applicant for higher education.

The inevitability of this trend is supported by the majority of well-known scientists didactics, scientists, psychologists, practicing teachers. In particular, the opinion of Michael Horn, co-founder of the American Clayton Christens Institute for Innovation in Education and co-author of "Blended Learning: Using Strong Innovations to Improve Schools", is quite popular. Michael Horn believes that adapting the educational process to the individual needs and capabilities of each student is the basis for both motivation and successful learning and quality education.

The realities of the present and the results of practical training indicate that in the context of a pandemic, the transition of institutions to online learning, the most effective is a blended learning model, because it involves a combination of the traditional education system with a software and online environment. According to Michael Horn, a student who is just acquiring fundamental knowledge and is building skills, does not need to read Shakespeare, but should instead be placed in a blended learning environment that has software and promotes basic literacy before moving on to a group discussion or conversation with a lecturer. Yes, you can agree with this opinion of the author, or not accept it. There are different statements of scientists and practical experts, but one thing is certain - a mixed environment helps students to reveal their individual talents and abilities, because it allows them to learn from anybody and anywhere, because there are no time or space constraints. An applicant for education can listen to lectures of famous scientists, scholars, lecturers at a distance in a convenient way and time.

Taking into account the above mentioned, we believe that it is very important to provide future specialists with the right of educational choice of forms, technics and methods of obtaining education - for them to be able to take responsibility for their own education, its further course and result, as well as professional formation and growth.

The purpose of the paper is to find out the essence of the problem of personalization and personification of vocational training at higher educational establishments in the present conditions.

\section{MAIN RESULTS}

To understand the essence of the personalized approach as a means of solving educational problems, it is important to clarify and expand the content of such concepts as "person", "personalization", "personification" and "personalized approach". In particular, the Dictionary of foreign words interprets the concept of "person": (lat. persona) as a person, personality, persona grata (desirable person) - a person whose candidacy as a diplomatic representative in any state is accepted by the government of that state (Tolkovyj slovar' inostrannyh slov). In Ch. Rycroft's "Critical Dictionary of Psychoanalysis" the term "person" is used as "a special concept to denote behavior that meets the requirements of an individual's everyday life" (Rycroft, 1995, p. 67). In the same dictionary we find the definition of the concept "personology", borrowed by M. Brierly to characterize the approach to the study of personality "not as an abstraction or a set of psychological abstractions, but rather as a living organism, an organic mental whole, which a person is" (Rycroft, 1995, p. 67). The scientist used this term to distinguish between the science about a person and metapsychology. In her opinion, the former preserves the personality, its individual experience, while the other understands a person as a result of the interaction of impersonal structures.

V. Dahl's Explanatory Dictionary defines the concept of "person" as a human, person, 
personality (Dal', 1989). According to C.G. Jung, the concept of a "person" is defined as the social role that the individual plays in accordance with the requirements addressed to him by the environment; "This is the public face of the individual, perceived by the others" (Psihologicheskij slovar). The term "person" today does not have a generally recognized single interpretation and is interpreted by the authors as a synonym for the concept of a "person" or a specific case of his or her characteristics.

So, "personalism" in psychology implies a special direction, the subject of which is person as a special primary reality. Personalism attributes the development of personality to the desire for self-actualization and internal self-improvement inherent in him or her from the very beginning, and considers all mental processes from the point of view of achieving this goal. Personalism is characterized by an idealistic and teleological explanation of the integrity and activity of a personality.

We consider it necessary to pay attention also to the problem of personalization. This term in the suggested meaning was introduced by A. Petrovskyi (Petrovskij, 1982). So, personalization is the process of acquiring of universal, socially significant, individually unique properties and qualities by a specific person, that allows him to perform a specific social role, communicate creatively, influence people's perception of themselves actively and assess his or her own personality and activities. We can assert that most scientists define "personalization" as a process due to which a subject acquires an ideal identification in other people's lives and is perceived as a person in public life. The essence of personalization consists in effective transformations of the sphere of an intellectual, affectively-requiring and different human, taking place as a result of an individual's activities. The need for personalization means being a specific person who is not always aware of the deep basis of many forms of communication between people (altruism, affiliation, striving for self-determination and recognition, etc.). The only efficient way to satisfy the need for personalization is activity, because it is with its help that a person continues himself, demonstrates to others his or her unique individuality.

The ability to personalize is determined by the totality of individual psychological characteristics of a person that allow him or her to perform socially significant actions that have a transformative effect on other people. It is provided by the richness of the subject's individuality, a variety of means by which he or she can perform a personalizing action in communication and activity.

The analysis of scientific publications showed that in modern science there are a number of works devoted to personified professional education (V. Kyselyov) and the personification of the educational process (Sh. Kalanova). Scientists in their research quite often resort to the identification of personified education with personality-oriented education, which is new and asks a number of questions to which there are no clearly substantiated answers in science and practice. Orienting training to determination of its personality-forming functions, the personified approach lays in the personality the mechanisms of understanding, mutual understanding, communication and cooperation. The content of the paradigm of personalized vocational education covers all aspects that a person needs for the formation and development of his or her own personality, regardless of the gained specialty. Scientists and practical experts identify personified education with an individual and personality-oriented process, because personified education is an individual, personality-oriented process aimed at a maximum social and professional development of a personality, based on his or her inherent desire for self-actualization and self-improvement.

Taking into account the above mentioned, we believe that personification is a pedagogical reality based on constantly active factors, conditions created in the educational process 
(socialization and inculturation of a personality, the image of an educator), prediction of possible difficulties and opportunities to overcome them (parents' authority, correction of development, obtaining informal education).

In our opinion, it is the personified approach that is an effective means of achieving the goal and implementation of the tasks of the humanistic concept of education, realized in the content and organizational forms of regionalization of the educational process, because dialogical activity involves the creation of special classrooms, the preparation of didactic material, excursions to historical and regional natural history places, the development of special courses, seminars, work in archives and libraries, presentations with reports at seminars, conferences, implementation of a personified approach in practice.

The definitions of the basic concepts of the article proposed by us do not give an exhaustive answer to what is the essence of the personification of the educational process and what value we attach to the personified approach. In addition to the above, the question arises about the legitimacy of the personified approach in education as directly related to the solution of regional problems. Personification, reflecting the humanistic paradigm of higher professional education, is a specific self-organization by a student of his or her personal educational space, actualizes his professional and personal development as a subject of free conscious choice of educational trajectories and ways to solve problems of professional development, awareness of his or her uniqueness and self-worth, which is a mechanism of self-realization and self-improvement.

The question of the approach to be chosen for use in vocational education also remains open: personified or personalized? In this context, among scientific sources, we are interested in V. Grachov's work “Theoretical foundations of personalization of the educational process in higher education" (Grachov, 2007). The author presents the personalization of the educational process as a "holistic image-project of its functioning and formation, which is taking shape under the sign of the student's transition to a personal position, that is, to the position of a subject of educational activity and the main spheres of life (cognitive, informational, scientific and innovative, social, cultural, managerial, etc. which are related to it) (Grachov, 2007, p. 8).

The conditions for ensuring the personalization of the educational process in higher education should also include the presence of a cultural impulse in the person of a socially conscious (national) idea-construction of society and a human, a cultural layer that provides for the development of science, art, technology, traditions of social and humanitarian thought, the presence of a wide range of expressions of volitions as opportunities for the implementation of constructive ideas, self-development and self-realization, gaining creative experience.

\section{CONLUSIONS}

The problem of personalization and personification of professional training requires an adequate psychological and pedagogical solution. In this regard, the leading task of reforming the educational domain is the need to rethink the goals of higher education based on understanding the phenomenology of personality formation in the educational process; the highest value of the educational environment of higher education is, first of all, the student's personality in the dynamics of development. The personal dimension, therefore, is the essence of the construction of the educational process, its theoretical foundations and practice. The approval of the universal human component for educational purposes requires a more humane approach to the study of a human, because personalization and personification of the educational process of vocational training requires the use of adequate technologies aimed at creating an integral educational space for personality development in the main spheres of his or her life. 


\section{REFERENCES}

Dal', V. (1989). Tolkovyy slovar zhivogo velikorusskogo yazyka (Vol.2). Russkiy yazyk.

Grachov, V. V. (2007). Teoreticheskie osnovy personalizacii obrazovatel'nogo processa v vysshej shkole [Extended abstract of Doctor's thesis, Moskovskij gumanitarnyj universitet].

Nesterenko, V. V. (2012). Do problemy personalizatsii osvitnoho protsesu u vyshchii shkoli. Naukovyi visnyk Donbasu: elektronne vydannia, 3(19).

Petrovskij, A. V. (1982). Lichnost. Deyatelnost. Kollektiv. Politizdat.

Psihologicheskij slovar. Persona. Retrieved November 16, 2021, from http://psi.webzone.ru/ st/334200.htm

Rycroft, Ch. (1995). Kriticheskij slovar psihoanaliza. VEIP.

Tolkovyj slovar' inostrannyh slov. Persona. Retrieved November 16, 2021, from http://www. onlinedics.ru/slovar/inyaz/p/persona.html 